\title{
Effect of Work Discipline and Work Motivation on Employee Productivity of PT. Denso Indonesia Plan 2 Cibitung Bekasi West Java
}

\author{
Eri Marlapa ${ }^{1}$ Tine Yuliantini ${ }^{2}$ Fajar Sidiq Ramadhan ${ }^{3}$ \\ Program S1 Manajemen Falkutas Ekonomi dan Bisnis \\ Universitas Mercu Buana Jakarta
}

\section{ABSTRACT}

The purpose of this study was to determine the effect of work discipline and work motivation on work productivity of PT. Denso Indonesia Plan 2 Cibitung Bekasi West Java. This research is a qualitative research. This research was conducted at PT. Denso Indonesia Plan 2 Cibitung Bekasi West Java, with a population of 192 employees. The sample in this study was random sampling (Probability Sampling) with a sample of 130 employees with a tolerance limit of 5\%. Data collection techniques using a questionnaire method, where all employees get the same opportunity to answer each question asked. Test the validity and reliability of the data using the product moment correlation formula from Pearson and Cronbach's Alpha. The data analysis technique used to test the hypothesis is multiple linear regression analysis. Based on the results of data analysis can be concluded, (1) there is a positive and significant effect of work discipline on the work productivity of employees of PT. Denso Indonesia Plan 2 Cibitung Bekasi West Java, (2) there is a positive and significant effect of work motivation on work productivity of PT. Denso Indonesia Plan 2 Cibitung Bekasi West Java.

Keywords: Work Discipline, Work Motivation and Work Productivity

DOI: $10.7176 / \mathrm{JRDM} / 60-07$

Publication date:October $31^{\text {st }} 2019$

\section{INTRODUCTION}

\section{A. Background}

In this free market era, business competition is very tight, companies must be able to continue to compete if they want to continue to survive in the competition in the free market era. The company continues to improve in all fields, so that employee productivity reaches the goals set. The aim of the company is to get the maximum profit and continue to survive for the long term. The company stands not only manage production, or assets owned, but human resources are an important component in the company to carry out all the company's vision and mission, in addition to machine assets, buildings, the most important assets of a company are human resources and the quality of human resources needs to be improved for work that is in accordance with the standards (Khumaidi 2016). Today's free market competition requires companies to be able to manage human resources properly and efficiently, as well as demonstrate good productivity so as to make the company grow and achieve the goals of the company.

The company makes strict regulations, to increase the productivity of its employees. Rules that are made to be obeyed and to serve as a guideline for employees in carrying out the work they do. But sometimes many employees feel that the rules made are burdensome for employees. The company requires discipline and regularity in working employees, so the company can measure the performance of its employees in completing their work. Employee discipline also reflects the character of individual employees, from the character it will be seen how employees are responsible for the work they lead. Good discipline reflects the magnitude of one's sense of responsibility in completing their work. Without discipline from employees, companies will find it difficult to get optimal results, because the performance of employees is not good. From discipline, the employee will emerge a good work passion, because this discipline forms a character of the employee. So the company can easily provide good motivation for its employees. So that its employees are able to complete the tasks given by the company optimally. productivity is the ratio of output to input which measures the effectiveness and efficiency of Wirawan's production (2015: 477). 


\begin{tabular}{|c|c|c|c|c|c|c|}
\hline \multirow[b]{2}{*}{ Production } & \multicolumn{2}{|l|}{2015} & \multicolumn{2}{|l|}{2016} & \multicolumn{2}{|l|}{2017} \\
\hline & Target & Real & Target & Real & Target & Real \\
\hline Radiator & $93,70 \%$ & $85,70 \%$ & $94,60 \%$ & $77,30 \%$ & $94,60 \%$ & $67,80 \%$ \\
\hline Condensor & $97,50 \%$ & $77,80 \%$ & $97,5 \% \%$ & $75,80 \%$ & $97,50 \%$ & $76 \%$ \\
\hline Hvac & $91 \%$ & $75 \%$ & $91 \%$ & $67,90 \%$ & $91 \%$ & $69 \%$ \\
\hline Tube & $91 \%$ & $75 \%$ & $91 \%$ & $70,70 \%$ & $91 \%$ & $69 \%$ \\
\hline $\begin{array}{l}\text { P-tank (Tank } \\
\text { Radiator) }\end{array}$ & $93,70 \%$ & $74 \%$ & $94,60 \%$ & $72,20 \%$ & $94,60 \%$ & $70 \%$ \\
\hline Fan Blower & $93,70 \%$ & $80,80 \%$ & $94,60 \%$ & $79 \%$ & $94,60 \%$ & $77 \%$ \\
\hline Magneto & $93,70 \%$ & $76 \%$ & $94,60 \%$ & $79 \%$ & $94,60 \%$ & $75,70 \%$ \\
\hline
\end{tabular}

Looking at the target data in the table above shows that there is instability in completing work each year, where the motivation of employees in completing work determines performance in work. Motivation questions how to direct the power and potential to work to achieve the goals specified Hasibuan (2017: 141). And discipline that is owned by employees is lacking, because of lack of motivation at work. Employee discipline can be seen in the table below (PT Denso Plan 2 Attendance Data).

Attendant list PT Denso Plan 2 Cibitung Bekasi Jawa Barat
List
attendant
Target

\begin{tabular}{lll}
\hline 2015 & $95 \%$ & $97 \%$ \\
\hline 2016 & $85 \%$ & $97 \%$ \\
\hline 2017 & $85 \%$ & $97 \%$ \\
\hline
\end{tabular}

Sources : HRD PT. Denso Indonesia Plan 2 Cibitung Bekasi Jawa Barat 2018

From the data in the table above it can be seen that the annual attendance of employees cannot reach the target of $97 \%$ attendance, even violations occur in employee absence. Due to lack of employee motivation at work, so discipline is owned by employees to decrease, and cause many violations, ranging from delays, and not present at work without explanation. This causes employee performance to be down. This can be seen in the table below (PT Denso Indonesia Plan 2 Employee Violation Data).

List of infraction PT Denso Indonesia Plan 2 Cibitung

Bekasi Jawa Barat

\begin{tabular}{lll}
\hline Year & Infraction & fine \\
\hline 2015 & 3 late coming on same month & Warning letter \\
\hline 2016 & 2 not coming on 3 days & Warning letter \\
\hline
\end{tabular}

2017

6 employees not coming without permit Meal coupon reduce

Based on the data in the table above there are still quite a lot of employees who violate company regulations, so getting a reprimand from the company, this can reduce the productivity of employees who often commit violations. Discipline applied by the company in addition to increasing employee productivity is to increase employee passion. Sometimes employees think that discipline tortures the right of freedom from employees, but discipline is actually a reflection of the character of someone who is responsible and achievers. But what happens is that employees do unplanned overtime, to cover working hours that are cut because of employee discipline and technical problems that occur in the company. Discipline is an attitude of willingness and willingness to obey and obey the norms of regulations that apply around it. Good employee discipline will accelerate Sutrisno's corporate goals (2013: 86). So it requires additional work hours to pursue production targets, and this causes overtime hours that have been set by the company towards employees to be irregular because the attitude of employees who work does not follow the rules of the company. 
Saluy and Treshia (2017) Research Results, states that discipline and motivation have a positive and significant impact on employee performance. Darmanto, Harahap (2015) suggested that discipline and motivation have a positive effect on employee performance. Furthermore Rumbewas, Suharnomo (2016) suggested that training, motivation, and work discipline have positive and significant $\mathrm{e}$

\section{LITERATURE REVIEW}

\section{Work productivity}

According to Wirawan $(2015: 477)$ productivity is the ratio of output (output) to input (input) which measures the effectiveness and efficiency of production. Whereas Hasibuan (2017: 94) argues that work productivity is a comparison between output and input, where outputs must have added value and better workmanship techniques. Productivity according to Sinugun (2014: 16) is grouped into three namely: 1. the traditional formula for overall productivity is nothing but the ratio of what is produced (output) to the entire production equipment used (input).

2. Productivity is basically a mental attitude that always has the view that the quality of life today is better than yesterday, and tomorrow will be better than today.

3. Productivity is a harmonious integrated interaction of three effective factors namely: investment including the use of knowledge and technology as well as research and labor.

\section{Work Discipline}

According Sutrisno (2016: 89) discipline is a person's behavior in accordance with regulations, existing work procedures or discipline is an attitude, behavior, and deeds in accordance with the regulations of the organization both written and unwritten. Meanwhile, according to Hasibuan (2017: 193), discipline is one's awareness and willingness to obey all company regulations and applicable social norms. Meanwhile, according to Mangkunegara (2015) work discipline is defined as the implementation of management to reinforce organizational guidelines.

\section{Work motivation}

According to Hasibuan (2017: 141) Motivation questions how to direct power and potential to work towards the specified goals. While Mangkunergara (2015: 93) argues that motivation is a condition that moves employees to be able to achieve the goals of their motives. Motive is an impulse of needs within the employee that needs to be met so that the employee can adjust to his environment. Motivation is a set of forces that cause people to engage in a behavior, not some other behavior (Moorhead and Griffin 2015: 86).

\section{Conceptual framework}

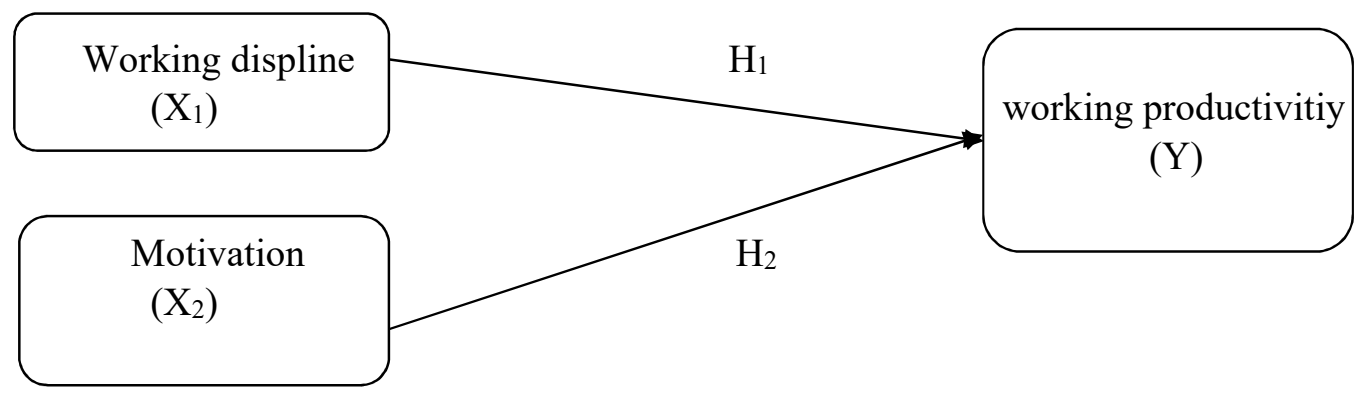

Hypothesis Development

Research from Manalu, Lumbanraja, Salim (2014), Diana, Dartu, Kustilah (2014), Assagaf, Dotulong (2015) states that work discipline influences employee work productivity.

$\mathrm{H} 1=$ Work discipline has an effect on employee work productivity.

Research from Assagaf, Dotulong (2015), Aspiyah, Martono (2016), Ratna (2017) states that motivation influences employee work productivity 
$\mathrm{H} 2$ = work motivation has an effect on employee work productivity

\section{RESEARCH METHODOLOGY}

This research uses quantitative research. Quantitative is can be interpreted as a research method based on the philosophy of positivism, used to examine the research instrument, quantitative or statistical data analysis, with the aim to test the hypothesis that has been set. Sugiyono (2015: 8). This study uses a causal approach that is a causal relationship Sugiyono (2015: 37). So in this study there are independent variables (work discipline and work motivation) and dependent (work productivity). This research will be assisted by the Statistical Product and Service Solution (SPSS) Version 22 program.

\section{Research Population}

Population according to Sugiyono (2015), "Population is a generalization area consisting of: objects / subjects that have certain qualities and characteristics that are determined by research to be studied and then conclusions drawn". In this study the population contained in PT Denso Indonesia Plan 2 West Java Production Division amounted to 192 Production employees.

\section{Research Samples}

Sample according to Sugiyono (2015), "The sample is part of the number and characteristics possessed by the population". In this study using a sampling technique that is Probability sampling. Probability sampling is a sampling technique that provides equal opportunities for each element (member) of the population to be selected as a sample member. In this study a sample of 130 people with a tolerance limit of $5 \%$.

\section{Data collection technique}

Data collection techniques are the means used to collect data and other information in research on problems that are the object of research. The sources and data collection techniques used are Primary data. Primary data collection is done by conducting a survey directly to PT. Denso Indonesia Plan 2 Cibitung Bekasi West Java as research objects. The purpose of this field research is to obtain accurate data. The data obtained by means of research is a questionnaire (questionnaire). The questionnaire is a primary data collection technique that is done by giving a set of questions or written questions to respondents to answer (Sugiyono, 2015: 142).

\section{DISCUSSION}

\section{Characteristics of respondents}

The majority of respondents were male, namely 100 respondents $(76.9 \%)$ while the remaining 30 respondents (23.1\%) were female. Most respondents were aged 21-30 years by 105 respondents (80.8\%) and the lowest respondents were aged $41-50$ years by 5 respondents $(3.8 \%)$. Respondents had the highest position, namely Manager with 2 respondents (1.5\%) and respondents with the lowest position were Operators with 104 respondents (80\%). Respondents who had the most high school graduates (high school) were 119 respondents $(91.5 \%)$ and the second most were S1 graduates at 8 respondents (6.2\%). respondents have the most work tenure of $1-5$ years $(106.5 \%)$ and the longest respondent is $16-20$ years of 1 respondent $(0.8 \%)$.

\section{Classic assumption test}

\section{Normality test}

The normality test is useful for testing whether in the regression model, the dependent variable and the independent variable have a normal distribution. The normality test is carried out on the basis of the Kolmogorov Smirnov (KS) test with $\mathrm{p} 2$ sides (two tailed) with the criteria used is if the results of the calculation of KS with 2 sides are greater than 0.05 then the data is normally distributed (Sugiyono 2015: 323).

In the Kolmogorov Smirnov Test study, decision making on the Kolmogorov Smirnov test obtained Sig values.

- If the Prob. /Sig F value is $>5 \%$, then the distribution is normal.

- If the Prob. /Sig F value is $<5 \%$, then the distribution is abnormal 


\begin{tabular}{lll}
\multicolumn{2}{l}{ Kolmogorov Smirnov test } \\
\multicolumn{2}{l}{ One-Sample Kolmogorov-Smirnov Test } \\
\hline \\
\hline $\mathrm{N}$ & Unstandardized Residual \\
\hline \multirow{2}{*}{ Normal Parameters ${ }^{\mathrm{a}, \mathrm{b}}$} & Mean & 130 \\
\hline & Std. Deviation & 00000 \\
\multirow{2}{*}{ Most Extreme Differences } & Absolute & 2.95707719 \\
& Positive & 0.089 \\
& Negative & 0.069 \\
\hline Kolmogorov-Smirnov Z & & -0.089 \\
\hline Asymp. Sig. (2-tailed) & & 1.013 \\
\hline
\end{tabular}

a. Test distribution is Normal.

b. Calculated from data.

The table above shows that the Asymp value. Sig. (2-tailed) obtained by $0.257>0.05$ means that the data is normally distributed.

\section{Multicollinearity Test}

Multicollinity is a state between two or more independent variables in a regression model where perfect or near perfect linear relationships occur. A good regression model requires the absence of multicollinearity, Ghozali (2013: 105). The purpose of the Multicollinearity test is to test whether the regression model found a correlation between independent variables. Multicollinearity test can be detected by calculating multiple coefficients and comparing them with the correlation coefficient between independent variables with the base value of VIF (Variant Inflation Factor). The criterion used is if the VIF value $<10$ and has a tolerance exceeding 0.1 , then it can be said there is no Multicollinearity problem.

\section{Multikolinearity test}

\begin{tabular}{|c|c|c|c|}
\hline \multicolumn{4}{|c|}{ Coefficients } \\
\hline \multirow{2}{*}{\multicolumn{2}{|c|}{ Model }} & \multicolumn{2}{|c|}{ Collinearity Statistics } \\
\hline & & Tolerance & VIF \\
\hline \multirow{3}{*}{1} & (Co & & \\
\hline & $\mathrm{X} 1$ & 0.128 & 7.799 \\
\hline & $\mathrm{X} 2$ & 0.128 & 7.799 \\
\hline
\end{tabular}

a. Dependent Variable: Y

The table above shows the variables of work discipline (X1) and work motivation (X2) each getting a tolerance value, $0.128>0.10$ and VIF $7.799<10$, then there is no Multicollinearity among the independent variables.

\section{Heteroskedaticity Test}

Heteroscedasticity test aims to test whether the regression model occurs Variance inequality from residuals of one observation to another. If the variance from one observation residual to another observation is fixed, then it is called Homoscedasticity and if different is called Heteroscedasticity. A good regression model is Homoscedasticity or Heteroskesdasticity does not occur. To detect the presence or absence of heteroskesdastisitas can be done by using a Scatterplot chart. (Ghozali, 2013: 139). As a basis for the analysis as follows:

a. If certain patterns, such as dots, form a regular pattern (wavy, widened and then narrowed), then it indicates that heteroscedasticity has occurred.

b. If there is no clear pattern, and the points spread above and below the number 0 on the $\mathrm{Y}$ axis, then there is no heteroscedasticity 


\section{Heteroskedastisitas test}

\begin{tabular}{|c|c|c|c|c|c|c|}
\hline \multicolumn{7}{|c|}{ Coefficients $^{\mathrm{a}}$} \\
\hline \multirow[b]{2}{*}{ Model } & & $\begin{array}{l}\text { Unsta } \\
\text { Coeff }\end{array}$ & $\begin{array}{l}\text { rdized } \\
\text { nts }\end{array}$ & $\begin{array}{l}\text { Standardized } \\
\text { Coefficients }\end{array}$ & \multirow[b]{2}{*}{$\mathrm{t}$} & \multirow[b]{2}{*}{ Sig. } \\
\hline & & $\mathrm{B}$ & $\begin{array}{l}\text { Std. } \\
\text { Error }\end{array}$ & Beta & & \\
\hline \multirow[t]{3}{*}{1} & (Constant) & .067 & .774 & & .086 & .932 \\
\hline & $\mathrm{T} \mathrm{X}_{1}$ & -.030 & .047 & -.155 & -.630 & .530 \\
\hline & $\mathrm{T} \mathrm{X}_{2}$ & .050 & .050 & .248 & 1.007 & .316 \\
\hline
\end{tabular}

a. Dependent Variable: ABS_RES

Based on the table above, it is known that the results of the Heteroscedasticity test show that the work discipline variable (X1) and work motivation (X2) get a value of sig. $>0.05$, so there is no heteroscedasticity in the regression model.

Determination Coefficient Test (R2)

According to Ghozali (2013: 97) the coefficient of determination (R2) is a tool to measure how far the ability of the model in explaining the variation of the dependent variable. The coefficient of determination is between 0 (zero) and 1 (one). A small R2 value means that the ability of the independent variables to explain the variation of the dependent variable is very limited. And conversely if a value close to 1 means that the independent variables provide almost all the information needed to predict the dependent variables.

\section{F statistic test}

\begin{tabular}{llllllll}
\hline \multirow{2}{*}{ Model } & SNOVA & & \\
& & $\begin{array}{l}\text { Sum } \\
\text { Squares }\end{array}$ & of & df & $\begin{array}{l}\text { Mean } \\
\text { Square }\end{array}$ & F & Sig. \\
\hline \multirow{3}{*}{1} & Regression & 129.413 & 2 & 64.707 & 9.495 & $.000^{\mathrm{b}}$ \\
\cline { 2 - 8 } & Residual & 865.479 & 127 & 6.815 & & \\
\cline { 2 - 8 } & Total & 994.892 & 129 & & & \\
\hline
\end{tabular}

a. Dependent Variable: T_PK

b. Predictors: (Constant), T_MTV, T_DS

Based on the table above shows that the results of the simultaneous hypothesis test or statistical test $\mathrm{F}$ produces an F-calculated value of 9.495 greater than F-table 3.9204 and a significant value of 0.000 less than 0.05 , meaning that simultaneously work discipline and work motivation have an effect simultaneously on work productivity. Thus, $\mathrm{H} 0$ is rejected and $\mathrm{H} 1$ is accepted. This means that the regression analysis tool used in this study is feasible to use and can be used to predict the independent variables (work discipline and work motivation) to the dependent variable (work productivity).

\section{Partial Test (t Test Statistics)}

T statistical test was conducted to partially test whether the independent variable had a significant effect on the dependent variable. In this test using a significant level of $(\alpha=5 \%)$. The hypothesis model that will be used is as follows:

a. $\mathrm{H} 0=$ the independent variable has no significant effect on the dependent variable

b. $\mathrm{H} 1=$ the independent variable influences the dependent variable.

With decision making criteria, if significance $<0.05$ then $\mathrm{H} 0$ is rejected and $\mathrm{H} 1$ is accepted, if significance $>0.05$ then $\mathrm{H} 0$ is accepted and $\mathrm{H} 1$ is rejected. 


\begin{tabular}{|c|c|c|c|c|c|c|}
\hline & & & $\begin{array}{l}\text { T test } \\
\text { efficients }^{\mathrm{a}}\end{array}$ & & & \\
\hline \multirow{2}{*}{ Model } & & $\begin{array}{l}\text { Unstai } \\
\text { Coeffi } \\
\end{array}$ & & $\begin{array}{l}\text { Standardized } \\
\text { Coefficients }\end{array}$ & \multirow[t]{2}{*}{$\mathrm{t}$} & \multirow{2}{*}{ Sig. } \\
\hline & & B & Std. Error & Beta & & \\
\hline \multirow{3}{*}{1} & (Constant) & 1,679 & 1,292 & & 1,300 & 0,196 \\
\hline & $\mathrm{X} 1$ & 0,555 & 0,79 & 0,571 & 7,050 & 0,000 \\
\hline & $\mathrm{X} 2$ & 0,400 & 0,83 & 0,390 & 4,817 & 0,000 \\
\hline
\end{tabular}

a. Dependent Variable: Y

Based on the table above the results of the work discipline hypothesis variable (X1) produces a count of 7.050 greater than $\mathrm{t}$ table $1.656(\mathrm{df}=127$; alpha 0.05$)$ and a significance value of 0.000 . Thus, $\mathrm{H} 0$ is rejected and $\mathrm{H} 1$ is accepted, so it can be concluded that work discipline has an effect on employee work productivity. As for the variable of work motivation, the count value of 4.817 is greater than t table $1.656(\mathrm{df}=127$; alpha 0.05$)$ and the signification value is 0.000 . Thus $\mathrm{H} 0$ is accepted and $\mathrm{H} 1$ is rejected, so it can be concluded that work motivation has an effect on employee work productivity.

Based on the above table, the regression equation can be made as follows:

$$
\mathrm{Y}=0.571 \mathrm{X} 1+0.390 \mathrm{X} 2
$$

The results of the regression equation on the significance of the coefficient and interpretation of the regression equation are as follows:

1. Work Discipline $(\mathrm{X} 1)=0.571$; if work discipline increases, employee productivity will increase

2. Work Motivation $(\mathrm{X} 2)=0.390$; if work motivation increases, employee productivity will increase

\section{Research result}

\section{Work Discipline Variable on Productivity}

Based on data processing through the distribution of questionnaires provided samples, researchers see the influence of work discipline which is very positive and significant on the work productivity of employees of PT. Denso Indonesia Plan 2 Cibitung Bekasi West Java, it can be seen that the value of count is 7.050 greater than $t$ table 1.656 with a significant level of 0.000 smaller than 0.05 . This means that the increase in work discipline, work productivity will increase significantly with the assumption that the other independent variables of multiple linear regression are fixed.

The results of this study are in line with the results of the research of Manalu, Lumbanraja, Salim (2014) entitled The Effect of Motivation, Leadership and Discipline on the Employee Productivity of the Forestry and Plantation Service Officers in Central Tapanuli Regency. Diana, Dartu, Kustilah (2014) The Effect of Work Discipline and Work Motivation on Employee Productivity in KP-RI Mekkar Purworejo. Saluy, Treshia in 2016 entitled the effect of Work Motivation, Work Discipline and compensation on the performance of employees of PT IE Jakarta.

\section{Variable of Work Motivation on Work Productivity}

Based on data processing through the distribution of questionnaires provided samples, researchers see the influence of positive and significant work motivation on the work productivity of employees of PT. Denso Indonesia Plan 2 Cibitung Bekasi West Java. This can be seen with the results of the tcount of 4.817 greater than $t$ table 1.656 with a significant level of significance value of 0.000 , smaller than 0.05 . This means that the increase in work motivation, employee productivity will increase significantly with the assumption that the other independent variables of multiple linear regression remain. This is in line with previous research Assagaf, Dotulong (2015), The Effect of Discipline, Motivation and Morale on Employee Work Productivity Manado Regional Revenue Service. Saluy and Treshia (2016) with the title Effect of Work Motivation, Work Discipline and Compensation on the Performance of PT IE Employees with the results of Work Motivation, Work Discipline and Compensation have a positive and significant effect on employee performance. Ratna (2017), the Effect of Work Motivation and Discipline on the Work Productivity of Production Employees at PT Gema Nusa Lestari Jambi. 


\section{CONCLUSION}

1. Work Discipline has a positive and significant effect on the Employee Productivity of PT. Denso Indonesia Plan 2 Cibitung Bekasi West Java, meaning that if employees have high work discipline, employee productivity will increase.

2. Work motivation has a positive and significant effect on the Employee Productivity of PT. Denso Indonesia Plan 2 Cibitung Bekasi West Java, meaning that if work motivation increases, employee productivity will increase.

\section{SUGGESTION}

\section{Work Discipline Variable}

Based on the results of the study states that work discipline affects work productivity of employees, based on the highest average indicators of employee behavior behave politely, suggestions for the company so that polite behavior in the company continues to be maintained so that productivity increases, whereas for indicators of resting ahead of time so that the sanctions increase can make employees able to improve themselves, and work productivity increases.

\section{Work Motivation Variable}

Based on the results of the study stated that work motivation affects the work productivity of employees of PT. Denso Indonesia Plan 2 Cibitung Bekasi West Java, with the highest average value with indicators of overtime incentives and attendance incentives, suggestions for companies to be able to maintain incentives so that employee motivation increases and work productivity increases. While the relationship between superiors and subordinates and coworkers, suggestions for companies to be able to unite so that cooperation is established well so that work productivity increases.

\section{Bibliography}

Abdullah,M. (2014). Manajemen dan Evaluasi Kinerja Karyawan, Yogyakarta:Aswaja Pressindo.

Ahmad Badawi Saluy, Yuwinta Treshia. (2016). Pengaruh motivasi kerja, disiplin kerja dan kompensasi terhadap kinerja karyawan pada PT IE Jakarta. Universitas Mercubuana Jakarta.

A.H. Rahadian, Mila Kencana (2016). Pengaruh Disiplin dan Motivasi Kerja Pegawai Terhadap Efektivitas Kerja Penanggulangan Bencana Alam Di Kecamatan Sukamakmur Kabupaten Bogor. STIAMI Bogor Jawa Barat

Annisa Pratiwi, Ismi Darmastuti. (2014) Pengaruh Motivasi dan Disiplin Kerja Terhadap Kinerja Pegawai Telkom Pekalongan. Universitas Diponegoro Semarang.

Cornelia Rumbewas, Suharnomo (2016). Analisis pengaruh pelatihan, motivasi dan disiplin kerja terhadap kinerja karyawan. Universitas Diponegoro Semarang.

Chandra Andhika Hadi Purnomo, M.Djudi, Yuniadi Mayoman (2017). Pengaruh Motivasi Kerja Dan Disiplin Kerja Terhadap Kinerja Karyawan PT Karoseri Tentrem Sejahtera Malang. Universitas Brawijaya Malang Jawa Timur.

Donni Junni Priansa. (2014). "Perencanaan \& Pengembangan SDM. Bandung: Alfabeta.

Evawati Khumaedi (2016) Pengaruh Disiplin Dan Motivasi Kerja Terhadap Kinerja Pegawai Pada Dinas Sentra Operasi Terminal PT. Angkasa Putra II, Jurnal Ilmiah Manajemen Dan Bisnis Vol. 2 nomor. 1.no. 486. Fakulta Ekonomi Dan Bisnis Universitas Mercu Buana Jakarta

Hasibuan, S.P Malayu. (2017). Manajemen Sumber Daya Manusia. Jakarta: Edisi Revisi. Bumi Aksara

Hamzah Hafied, (2016). Manajemen Sumber Daya Manusia . Makassar: Kretakupa Print.

Hariandja,Marihot Tua Efendi. (2014). Manajemen sumber daya manusia. (Edisi Revisi.) Jakarta: PT Grasindo

Kadarisman,M . (2015), Manajemen Kompensasi, Depok : RajaGrafindo Persada

Mangkunegara Anwar Prabu (2015). Manajemen Sumber Daya Manusia. Perusahaan. PT.Remaja Rosda Karya, Bandung.

Michael Zimmer and Nicholas John Proferes (2013). A topology of Twitter research: disciplines, methods, and ethics. School of Information Studies, University of Wisconsin-Milwaukee, Milwaukee, Wisconsin, USA

Nur Avni Rozalia, Hamida Nayati Utami, Ika Ruhana (2015). Pengaruh Motivasi Dan Disiplin Kerja Terhadap Kinerja Karyawan PT Pattindo Malang. Universitas Brawijaya Malang Jawa Timur.

Rivky Pomalingo, Silvya L Mandey, Yantje Uhing.(2015) Pengaruh Disiplin, Kompetensi, Dan Motivasi Terhadap Kinerja Pegawai Pada Kantor Badan Penanggulangan Bencana Daerah Provinsi Sulawesi Utara. Universitas Sam Ratulangi Manado.

Siagian,Sondang(2014). Manajemen Sumber Daya Manusia. Jakarta : BumiAksara

Sugiyono. (2015). Metode Penelitian Kuantitatif Kualitatif dan R\&D. Bandung: Alfabeta 
Sutrisno. 2016. Manajemen Sumber Daya Manusia. Jakarta : Prenadamedia Group.

Sanjak Kutnjak Ivkovic And Robert Peacock (2015). Does discipline fairness matter for the police code of silence? Answers from the US supervisors and line officers. School of Criminal Justice, Michigan State University, East Lansing, Michigan, USA,

Tubagus A. Darojat (2015:163). Pentingnya Budaya Kerja Tinggi dan Budaya Kerja Kuat. PT Refika Aditama, Bandung

Wirawan, (2015). Manajemen Sumber Daya Manusia Indonesia.Depok : RajaGrafindo Persada 